\title{
Sanção de ressarcimento ao erário por improbidade administrativa
}

\author{
Supremo Tribunal Federal (STF)
}

\section{Recurso Extraordinário 852.475 São Paulo}

\section{Voto}

1. O presente voto, ao dispor aos eminentes pares e às partes a respectiva íntegra, expressa fundamentação nos termos do inciso IX do art. 93 da Constituição da República Federativa do Brasil, e se contém em aproximadamente 10 (dez) páginas. A síntese e conclusão podem ser apresentadas, sem prejuízo da explicitação no voto contida, à luz do procedimento que se fundamenta nos termos do insculpido no inciso LXXVIII do art. 5o da Constituição Federal de 1988, em cuja abrangência se insere a celeridade de julgamento, mediante sucinta formulação que tem em conta as seguintes premissas e arremate:

\subsection{Premissas:}

Primeira: a prescrição é instituto que milita em favor da estabilização das relações sociais e, assim, a uma dimensão específica do princípio da segurança jurídica, estruturante do Estado de Direito.

Segunda: Há, no entanto, uma série de exceções explícitas no texto constitucional, como a prática dos crimes de racismo (art. 5으, XLII, CRFB) e da ação de grupos armados, civis ou militares, contra a ordem constitucional e o Estado Democrático (art. 5으, XLIV, CRFB). Nesse mesmo rol está o dispositivo previsto no art. $37, \S 5$ 으, CRFB. 
Terceira: o texto constitucional é expresso ao prever que a lei estabelecerá os prazos de prescrição para ilícitos na esfera cível ou penal, aqui entendidas em sentido amplo, que gerem prejuízo ao erário e sejam praticados por qualquer agente. Logo em seguida, porém, decota de tal comando para o Legislador as ações cíveis de ressarcimento (ou seja, de recomposição) do erário, tornando-as, assim, imprescritíveis.

Quarta: São, portanto, imprescritíveis as ações de ressarcimento ao erário fundadas na prática de ato de improbidade administrativa.

\subsection{Base constitucional: artigo $37, \S \S 4^{\circ}$ e $5^{\circ}$, CRFB.}

1.3. Base em precedentes: $o$ voto se estriba em precedentes que formam jurisprudência deste Tribunal; especificamente cita-se o seguinte: RE 669.069, Rel. Min. Teori Zavascki, Tribunal Pleno, julgado em 03.02.2016

1.4. Conclusão: voto pelo parcial provimento do recurso extraordinário para (i) afastar a prescrição da sanção de ressarcimento e (ii) determinar que o tribunal recorrido, superada a preliminar de mérito pela imprescritibilidade das ações de ressarcimento por improbidade administrativa, aprecie o mérito apenas quanto à pretensão de ressarcimento.

Tese de julgamento: São imprescritíveis as ações de ressarcimento ao erário fundadas na prática de ato doloso tipificado na Lei de Improbidade Administrativa.

O SENHOR MINISTRO EDSON FACHIN: Adoto o bem lançado relatório proferido pelo e. Ministro Alexandre de Moraes.

Conforme consignou Sua Excelência, trata-se de recurso extraordinário interposto em ação de improbidade administrativa em que se pleiteia a aplicação das sanções previstas no art. 12, II e III, da Lei no 8.429/92. A apelação foi provida pelo e. Tribunal de Justiça do Estado de São Paulo para reconhecer a ocorrência da prescrição e dispensar os servidores do ressarcimento de danos.

Discute-se, portanto, a prescritibilidade da pretensão de ressarcimento ao erário em face de agentes públicos em decorrência de alegado ato de 
improbidade administrativa.

\section{Era o que havia a rememorar.}

Trago algumas considerações que auxiliam a descortinar aquela que, em meu sentir, é a interpretação mais adequada do dispositivo previsto no art. 37, $\S 5$ o, da Constituição da República.

Consigno desde já que este último elemento - a República - constitui a moldura institucional construída pela Constituição e caracteriza nitidamente um Estado Constitucional e Democrático de Direito que tem como seus alicerces a cidadania, a dignidade da pessoa humana e o pluralismo político (art. 1으, II, III, e V, CRFB).

Bem por isso, não há espaço aqui para se pensar a partir de um republicanismo totalizante, em que o ideal de cidadania ativa aniquile a dimensão individual e a diversidade típica das democracias constitucionais contemporâneas.

É salutar que se levem a sério os compromissos fundamentais, especialmente - no que interessa - aqueles que materializam a proteção da coisa pública e da probidade administrativa, incorporados à narrativa constitucional pátria como virtudes republicanas.

Discute-se, no recurso extraordinário em julgamento, a prescritibilidade da pretensão de ressarcimento ao erário em face de agentes públicos em decorrência de suposto ato de improbidade administrativa. Reproduzo a ementa do acórdão recorrido:

Ação Civil Pública - Licitação - Alienação de bens móveis - Avaliação abaixo de preço de mercado - A Lei Federal no 8.112/90 dispõe que a ação disciplinar prescreve em 5 (cinco) anos quanto às infrações puníveis com demissão (inciso I), sendo que o prazo prescricional começa a correr da data em que o fato se tornou conhecido $\left(\S 1^{\circ}\right)-$ Fatos ocorridos em 26.04.1995 e 21.11.1995 - Ação interposta em 03.07.2001 — Ocorrência da prescrição - Ação julgada extinta em relação aos ex-servidores. Recurso provido.

No julgamento do RE 669.069 (Tema 666), de relatoria do saudoso Ministro Teori Zavascki, quando fiquei vencido, esta Corte assim assentou:

CONSTITUCIONAL E CIVIL. RESSARCIMENTO AO ERÁRIO. IMPRESCRITIBILIDADE. SENTIDO E ALCANCE DO ART. 37, §5으, DA 
CONSTITUIÇÃO. 1. É prescritível a ação de reparação de danos à Fazenda Pública decorrente de ilícito civil. 2. Recurso extraordinário a que se nega provimento. (RE 669069, Rel. Min. Teori Zavascki, Tribunal Pleno, julgado em 03.02.2016).

Como se vê, naquela ocasião, firmou-se tese restrita aos casos de ilícito civil, que não alcança as ações de ressarcimento ao erário fundadas em atos tipificados como ilícitos de improbidade administrativa.

Dessa forma, a questão constitucional devolvida a esta Corte pelo presente recurso é a aplicação da imprescritibilidade constitucional para as ações de ressarcimento decorrentes de atos de improbidade administrativa.

Permito-me fazer remissão aos fundamentos que adotei quando do julgamento do RE 669.069, de relatoria do saudoso Ministro Teori Zavascki, já mencionado.

1ํ - Texto Expresso da Constituição: impossibilidade da restrição dos ilícitos aptos a ensejar ação de ressarcimento e diferenciação do âmbito de incidência, na tutela da coisa pública, dos $\S \S 4^{\circ}$ e $5^{\circ}$ do art. 37.

Como é sabido, a prescrição é instituto que milita em favor da estabilização das relações sociais e, assim, a uma dimensão específica do princípio da segurança jurídica, estruturante do Estado de Direito. Bem por isso, a regra geral no ordenamento jurídico é de que as pretensões devem ser exercidas dentro de um marco temporal limitado.

Há, no entanto, uma série de exceções explícitas no texto constitucional, como a prática dos crimes de racismo (art. 5ㅇ, XLII, CRFB) e da ação de grupos armados, civis ou militares, contra a ordem constitucional e o Estado Democrático (art. 5ํㅜ XLIV, CRFB).

Entendo que nesse mesmo rol está o dispositivo previsto no art. 37, §5으, CRFB, vazado nos seguintes termos:

§5ํ A lei estabelecerá os prazos de prescrição para ilícitos praticados por qualquer agente, servidor ou não, que causem prejuízos ao erário, ressalvadas as respectivas ações de ressarcimento.

Inserido no Título III da Constituição, que trata da Organização do Estado, mais especificamente em seu Capítulo VII, que versa sobre a Administração 
Pública, em que se estabelece a imperiosidade de obediência aos princípios da legalidade, impessoalidade, moralidade, publicidade e eficiência (art. 37, caput), faz parte, em meu sentir, da arquitetura constitucional de proteção da coisa pública.

É certo que a previsão de graves sanções para os atos de improbidade administrativa e a imperiosidade de sua normatização legal (presentes nos arts. $14, \S 9$ o $, 15, \mathrm{~V}$, e $37, \S 4$ o ${ }^{\circ}$ CRFB) também se inserem no mesmo quadrante de proteção e tutela da coisa pública.

No entanto, tais previsões não devem gerar confusão ou conflito com o disposto no art. 37, §5으, CRFB. Nesse dispositivo, o texto constitucional é expresso ao prever que a lei estabelecerá os prazos de prescrição para ilícitos (quer, portanto, na esfera cível ou penal, aqui entendidas em sentido amplo) que gerem prejuízo ao erário e sejam praticados por qualquer agente. Logo em seguida, porém, decota de tal comando para o Legislador as ações cíveis de ressarcimento (ou seja, de recomposição) do erário, tornando-as, assim, imprescritíveis.

O texto constitucional é expresso ao prever a ressalva da imprescritibilidade da ação de ressarcimento ao erário. Não nomeia, elenca, particulariza e nem restringe a natureza dos ilícitos que geram danos e que, assim, podem ensejar o ressarcimento dos danos ao erário. Basta haver dano. Se houver dano poderá haver ação de ressarcimento, sem que incida sobre essa pretensão qualquer prazo prescricional. Basta, à luz do comando constitucional, a existência de ilícito que a ele cause prejuízo para que seja possível ação de ressarcimento, sem que sobre a pretensão nela veiculada incida qualquer prazo prescricional.

Houve, assim, por escolha do poder constituinte originário, não apenas o alçamento da boa governança a patamar constitucional, mas da compreensão da coisa pública - não raras vezes tratada com desdém, vilipendiada por agentes particulares ou estatais - como um compromisso fundamental a ser protegido por todos.

O comando estabelece como um verdadeiro ideal republicano que a ninguém, ainda que pelo longo transcurso de lapso temporal, é autorizado ilicitamente causar prejuízo ao erário, locupletando-se da coisa pública ao se eximir do dever de ressarci-lo.

Frise-se, ainda, que esse entendimento não significa nem pode significar que se tornariam imprescritíveis todos os créditos públicos passíveis de inscrição em dívida ativa e cobrança mediante execução fiscal.

Sem descer às minúcias das regras infraconstitucionais de Direito Tri- 
butário e Financeiro, no que se refere à maior parte da dívida ativa não tributária (como, por exemplo, as dívidas decorrentes de multas no exercício do poder de polícia), incide a regra geral da prescritibilidade como postulado da segurança jurídica e como matéria regida por legislação específica sem qualquer ressalva no texto constitucional.

Quanto à dívida tributária, o próprio texto constitucional estabelece caber à lei complementar estabelecer normas gerais em matéria de legislação tributária, especialmente sobre "obrigação, lançamento, crédito, prescrição e decadência tributários" (art. 146, III, b, CRFB), fixando textualmente a sua prescritibilidade, a ser definida em lei, e sem também fazer qualquer ressalva expressa.

\section{2o - "Agente" como aquele que pratica ato ilícito que gera prejuízo ao erário.}

O disposto no art. 37, §5ำ é nítido ao prever que a lei estabelecerá os prazos prescricionais dos ilícitos praticados "por qualquer agente, servidor ou não". Ou seja, o art. 37, §5o é cristalino ao estabelecer a prescrição dos atos ilícitos como regra, independentemente da qualidade do agente, quer seja ou não ele agente estatal (servidor público). Igual entendimento, portanto, deve se aplicar à ressalva no que se refere à imprescritibilidade das pretensões de caráter ressarcitório dos prejuízos sofridos pelo erário. Recorde-se que tal compreensão está em consonância com a ideia exposta neste voto de que a exceção prevista nesse dispositivo é um compromisso republicano, respeitando igualmente o princípio constitucional da isonomia como importante corolário do princípio da dignidade da pessoa humana, fundante de nossa República (arts. 1은, III, e 5o, caput, CRFB).

Ademais, a Lei de Improbidade Administrativa (Lei no 8.429/1992) também não restringe a prática de atos de improbidade aos servidores públicos, nos termos dos arts. 1ำ a 3 ㅇ:

Art. $1^{\circ}$ Os atos de improbidade praticados por qualquer agente público, servidor ou não, contra a administração direta, indireta ou fundacional de qualquer dos Poderes da União, dos Estados, do Distrito Federal, dos Municípios, de Território, de empresa incorporada ao patrimônio público ou de entidade para cuja criação ou custeio o erário haja concorrido ou concorra com mais de cinquenta por cento do patrimônio ou da receita anual, serão punidos na forma desta lei.

Parágrafo único. Estão também sujeitos às penalidades desta lei os atos 
de improbidade praticados contra o patrimônio de entidade que receba subvenção, benefício ou incentivo, fiscal ou creditício, de órgão público bem como daquelas para cuja criação ou custeio o erário haja concorrido ou concorra com menos de cinquenta por cento do patrimônio ou da receita anual, limitando-se, nestes casos, a sanção patrimonial à repercussão do ilícito sobre a contribuição dos cofres públicos.

Art. $2^{\circ}$ Reputa-se agente público, para os efeitos desta lei, todo aquele que exerce, ainda que transitoriamente ou sem remuneração, por eleição, nomeação, designação, contratação ou qualquer outra forma de investidura ou vínculo, mandato, cargo, emprego ou função nas entidades mencionadas no artigo anterior.

Art. 3o As disposições desta lei são aplicáveis, no que couber, àquele que, mesmo não sendo agente público, induza ou concorra para a prática do ato de improbidade ou dele se beneficie sob qualquer forma direta ou indireta.

Diante disso é de se inferir da redação do art. 37 , §5, que o texto constitucional, ao tratar do sujeito praticante dos atos ilícitos, se refere a "agente", de forma lata, genérica. Vale dizer, ao se referir a agente praticante de ato ilícito, submetido à regra prescricional a ser prevista em lei, o art. 37, §5으 se refere ao agente que pratica atos ilícitos danosos ao erário. A eles se aplicarão as regras específicas de prescrição dos referidos atos. Mas, não se isentarão das ações de ressarcimento, independentemente da sua qualidade de agente, independentemente da natureza do ilícito que tenham praticado.

\section{$3^{\circ}$ - Segurança Jurídica.}

Diante da exceção constitucional ampla que estabelece a imprescritibilidade das pretensões de ressarcimento do erário decorrentes de atos ilícitos que a ele causaram prejuízos, entendo que a sua restrição a um grupo específico de ilícitos (sejam eles improbidade administrativa ou tipos penais), ao contrário de favorecer, milita em desfavor ao princípio da segurança jurídica.

O comando constitucional materializou, com segurança, o ideal republicano de que ninguém, ainda que pelo transcurso de lapso temporal considerável - frise-se uma vez mais - está autorizado ilicitamente a causar prejuízo ao erário, locupletando-se da coisa pública ao se eximir do dever de ressarci-lo.

O ponto foi bem percebido no parecer da Procuradoria Geral da Repú- 
blica apresentado nos autos, verbis:

A imprescritibilidade representa, antes, garantia da coletividade à restituiç̧ão do que lhe foi subtraído pelo ato de improbidade, a partir de violações de princípios constitucionais caros à população como um todo e do dever de lealdade para com as instituições.

Exatamente por isso, no tocante à improbidade administrativa, a tutela conjunta dos interesses é reclamada pela ordem constitucional. Não há como dissociar a tutela dos interesses defendidos da regulamentação da ação de improbidade, inobstante a circunstância de cada uma das lesões advindas do comportamento ímprobo gerar consequências distintas (sanções punitivas e reparação de dano).

O dano ao patrimônio público é o resultando, dando o Poder Constituinte preponderância não a ele, mas à forma como é gerado (improbidade). Daí a possibilidade, ou melhor, necessidade, de permitir que se dê prosseguimento à ação de improbidade a fim de que, mesmo prescritas as demais sanções, seja alcançada a reparação do dano ao erário, de natureza imprescritível. (eDOC 26, p. 23/24).

Tendo ciência da imprescritibilidade constitucional, não se trata aqui de gerar uma injustificada e eterna obrigação de guarda, pelo particular, de elementos probatórios aptos à conclusão de que inexiste o dever de ressarcir, mas sim da afirmação de importante proteção da coisa pública da qual também ele é titular.

\section{A resolução do caso concreto.}

O caso concreto diz respeito a ação de improbidade administrativa, ajuizada em 03.07.2001, em razão de fatos ocorridos em 26.04.1995 e 21.11.1995.

O Tribunal de Justiça do Estado de São Paulo decidiu o caso, no mérito, reconhecendo e decretando a ocorrência de prescrição quinquenal, aplicando aos servidores, na hipótese, por analogia, o prazo do art. 142, I, da Lei no $\div$ 8.112/1990.

Diante do exposto, voto pelo parcial provimento do recurso extraordinário para (i) afastar a prescrição da sanção de ressarcimento e

(ii) determinar que o tribunal recorrido, superada a preliminar de mérito pela imprescritibilidade das ações de ressarcimento por improbidade administrativa, aprecie o mérito apenas quanto à pretensão de ressarcimento. 
É como voto.

Tese de julgamento: São imprescritíveis as ações de ressarcimento ao erário fundadas na prática de ato doloso tipificado na Lei de Improbidade Administrativa. 